REGIONAL STATISTICS, 2012, VOL. 2: 45-60 DOI: 10.15196/RS02104

JUDIT GÉBERT - GYÖRGY MÁLOVICS - ZSUZSA FÁSKERTI

\title{
The Limits of Well-being Measurement at Sub-regional Level
}

\section{Introduction}

To characterise the well-being of different regions, certain indices of the System of National Accounts (SNA) are used by the national and international literature. However, it is already evident that the informational base of the SNA and especially its most popular indicators (e.g. GDP, GNP) is very narrow. This base does not contain even basic information about the state of the natural environment, the effect of economic processes on nature, and several other aspects of social well-being (Sen 1999, van den Bergh 2007, Stiglitz et al. 2009).

Consequently, many organisations and researchers have recently attempted to create systems of indicators to represent more aspects of general well-being and sustainable development. As a result of this tendency in research projects, more than 500 sets of indicators aiming to operationalise sustainable development are mentioned in a recent study (Böhringer-Jochem 2007). Besides this fact, every significant international organisation (like the EU, UN, OECD, etc.) has its own indicator system for sustainability. In 2003, the UN, the European Commission, the IMF, the OECD and the World Bank published a proposal for a framework for integrated environmental and economic national accounts (Eurostat 2007, Hungarian Central Statistical Office 2008, OECD 2003, UN 2007, UNECE et al. 2008). These sustainability indicator sets all have their 'well-being' pillar, namely they all contain indicators which aim to provide information on the present level of social well-being. In our paper we concentrate on this, well-being measurement.

Recently, a committee led by Nobel laureate economists published a report on the insufficiency of the dominant welfare indicators and the desirable criteria for an alternative indicator system (Stiglitz et al. 2009). These facts suggest that there are valid arguments to use alternative indices in political decision-making in order to obtain a better understanding of the well-being of societies.

In our paper, we aim to establish a system of well-being indicators for the subregional level. Thus, our work contributes to a better understanding of present social well-being at this level of analysis.

Our paper consists of three parts. In the first, we describe the theoretical background and the methodology. On the basis of contemporary well-being theories, we create an overall well-being typology. This typology includes the ideal well-being measures for the sub-regional level. After that, we describe the process of the operationalisation of the well-being measures and specifically those tools which are available for the sub-regional level to determine the level of prosperity in Hungary. Lastly, the average well-being rates in Hungary are analysed at sub-regional level with the help of multivariate statistical 
methods. In this part of the paper, we introduce our results in a national comparison. In the final section of the paper, we draw conclusions from our results and from our theoretical underpinning. Our main findings are that (1) well-being measurement at a sub-regional level reveals tendencies which are masked by traditional economic and competitiveness analysis; and (2) a measurement exercise like ours has serious limitations, i.e. there is a significant measurement gap between theoretical models of well-being and their operationalisation, most of all because of the current state of data availability.

\section{Methodology and theoretical background}

As the first step of our research we overviewed the current literature on well-being theories - utility-based approaches (Hausmann-McPherson 1997), basic resources (or needs) (Rawls 1971, Streeten 1979) and the capability approach (Sen 1993, 1995, 1999, Nussbaum 2011, Comim et al. 2008). The main components of these approaches can be seen in Table 1.

Table 1

Theories about well-being

\begin{tabular}{|c|c|c|}
\hline Utility-based approach & Basic needs, resources & Capability approach \\
\hline $\begin{array}{l}\text { Income } \\
\text { Unemployment }\end{array}$ & $\begin{array}{l}\text { Rawls (1997): } \\
\text { Basic rights and liberties } \\
\text { Powers of offices and positions } \\
\text { of responsibility } \\
\text { Income and wealth } \\
\text { Social bases of self-respect } \\
\text { Streeten (1979): } \\
\text { Means for bare survival } \\
\text { Means for continued survival } \\
\text { Means for productive survival } \\
\text { Non-material needs }\end{array}$ & $\begin{array}{l}\frac{\text { Sen }(1999):}{\text { Real opportunities }} \\
\text { Nussbaum (2011): } \\
\text { Life } \\
\text { Bodily health } \\
\text { Bodily integrity } \\
\text { Senses, imagination and thought } \\
\text { Emotions } \\
\text { Practical reason } \\
\text { Affiliation } \\
\text { Other species } \\
\text { Play } \\
\text { Control over one's environment }\end{array}$ \\
\hline
\end{tabular}

We do not intend to choose between the different theories, which all have their own theoretical underpinning. Instead, we synthesise these contemporary theories of wellbeing in a new theoretical framework and use the notion of 'dimension', which was suggested by Alkire (2002). We define dimension as follows: a dimension is any of the component aspects of well-being (Alkire 2002). So a dimension is a kind of aspect or viewpoint that captures a part of well-being. While one single dimension cannot give a full picture of well-being, there is no requirement that dimensions of well-being must be free of overlap. Our aim with this notion is to interpret well-being according to the results of contemporary welfare economics from the broadest possible base of information.

According to the aforementioned well-being theories, we compiled the following list of dimensions (Table 2). 


\section{Dimensions of well-being}

\begin{tabular}{|c|c|}
\hline 1. Financial goods & $\begin{array}{l}\text { All of the theories about well-being admit that we need certain material and } \\
\text { financial goods to survive. But both the basic resources approaches and the } \\
\text { capability approach emphasise that financial and material goods are just means } \\
\text { to achieve well-being and not goals in themselves. }\end{array}$ \\
\hline 2. Rights for freedom & $\begin{array}{l}\text { Some of the authors on well-being (Rawls 1971, Nussbaum 2011) attribute } \\
\text { significance to basic human rights for freedom (like freedom of movement, free } \\
\text { choice among a wide range of occupations, freedom to take part in decision- } \\
\text { making, etc.), which cannot be alienated from both intrinsic and instrumental } \\
\text { reasons. }\end{array}$ \\
\hline 3. Physical well-being & $\begin{array}{l}\text { To live a long life, people prima facie need health. Things which are needed for } \\
\text { survival and for being healthy belong to this dimension, like drinking water, } \\
\text { food, shelter, sanitation, etc. According to the capability approach, health is the } \\
\text { most important means of achieving valuable goals in life (Sen 1999). }\end{array}$ \\
\hline $\begin{array}{l}\text { 4. Relationship with } \\
\text { family/friends }\end{array}$ & $\begin{array}{l}\text { Having relationships with other members of society, playing with them, having } \\
\text { emotions about them are among the most important capabilities according to } \\
\text { Nussbaum (2011), but this is mentioned in basic goods theories as well. }\end{array}$ \\
\hline 5. Quality of environment & $\begin{array}{l}\text { The quality of the environment is neglected by the mainstream economic } \\
\text { theories. However, this important factor is not just intrinsically valuable, but it } \\
\text { is also the basis for other elements of well-being like clean drinking water, } \\
\text { healthy food, safe environment, etc. }\end{array}$ \\
\hline 6. Leisure activity & $\begin{array}{l}\text { Being able to play is mostly emphasised by Nussbaum. According to the } \\
\text { capability approach, life is more valuable if people have a wide variety of } \\
\text { leisure activities, like cinema and theatre going, sports, civil activities, etc. }\end{array}$ \\
\hline 7. Labour & $\begin{array}{l}\text { Labour, as one of the factors of production, has an important role in economic } \\
\text { theories and competitiveness analysis. However, having a job also gives people } \\
\text { self-esteem, thus it is another important dimension (Sen 1999). }\end{array}$ \\
\hline 8. Forms of social care & $\begin{array}{l}\text { Forms of social care are services which are provided by the community. These } \\
\text { services cannot be created by individuals on their own. }\end{array}$ \\
\hline 9. Education & $\begin{array}{l}\text { Education has prior importance in widening the capabilities of individuals. } \\
\text { More educated people produce more value-added products and services, and } \\
\text { have a better chance of getting a job (Sen 1999). }\end{array}$ \\
\hline 10. Information access & $\begin{array}{l}\text { According to the capability approach, to live a valuable life, people need to get } \\
\text { information about the world in general, such as about job opportunities, } \\
\text { political actions, etc. (Sen 1999). But Rawls also emphasises the right to be } \\
\text { informed (1971). }\end{array}$ \\
\hline $\begin{array}{l}\text { 11. Basis of social } \\
\text { self-respect }\end{array}$ & $\begin{array}{l}\text { The basis of social self-respect means recognition by social institutions that } \\
\text { gives a sense of self-worth to citizens. People need certain goods to be full } \\
\text { members of society, like appropriate clothing, communication devices, etc. } \\
\text { (Rawls 1971). }\end{array}$ \\
\hline
\end{tabular}

Source: Own illustration.

In the second step of our research, we established our set of indicators. To grasp the sub-regional dimension of the statistical indicators of well-being, our database relied on data from TeIR and, most of all, on the data of the Hungarian Central Statistical Office. Exceptions are income data, which originate from the tax authority. The resultant 
database of potential well-being indicators consists of 58 welfare indicators, all of which can be linked to a dimension of well-being (Appendix 1).

The concept of dimension according to Alkire (2002) is then divided into three levels in order to classify potential well-being indicators. These are: (1) Theoretical main dimension, (2) Dimension and (3) Sub-dimension. The theoretical main dimensions refer to the 11 dimensions based on theory. The other two levels (dimension and subdimension) represent a more detailed conceptual analysis, virtually a group of indicators. These were created by using factor analysis.

The indicators we actually used for our analysis were selected after a multi-step process. All of the 58 indicators were classified into one of the theoretical main dimensions on the basis of well-being theories. Unfortunately, we did not manage to find indicators for 5 of the previously defined 11 theoretical well-being dimensions. Thus indicators were available in the following six theoretical main dimensions:

1. Financial goods

2. Physical well-being

3. Leisure activities

4. Labour

5. Forms of social care

6. Education

We standardised our variables, and created specific and rate indicators to be able to compare the results of the sub-regions. After standardising the variables, we made different factors (sub-dimensions) by principal component analysis from the standardised variables in the theoretical main dimensions. Our set of indicators consists of three levels, as mentioned above, which can be seen in Figure 1. The theoretical main dimensions are lined up according to the theoretical literature and are in accordance with Alkire's dimensions of well-being. The sub-dimensions represent one given aspect of well-being and they can be handled as single factors in our model because of their empirical connection.

We created the level of dimensions in our analysis, which is between the level of main dimensions and sub-dimensions (Figure 1). From a theoretical perspective, this level reflects the constituents of well-being, which are narrower than the theoretical main dimensions, but broader than the sub-dimensions. Moreover, when analysing the indicators in one dimension by the principal component method, we found that the indicators within one dimension were part of the same model with at least $70 \%$ explanatory power, thus one dimension can be considered as one single unit. Accordingly, the actually used set of indicators consists of standardised variables, which are connected strongly and unequivocally to the factors (or main components) from the principal component method. Thus we have 47 indicators, classified into 23 subdimensions (factors). 


\section{Levels of indicators}

Figure 1

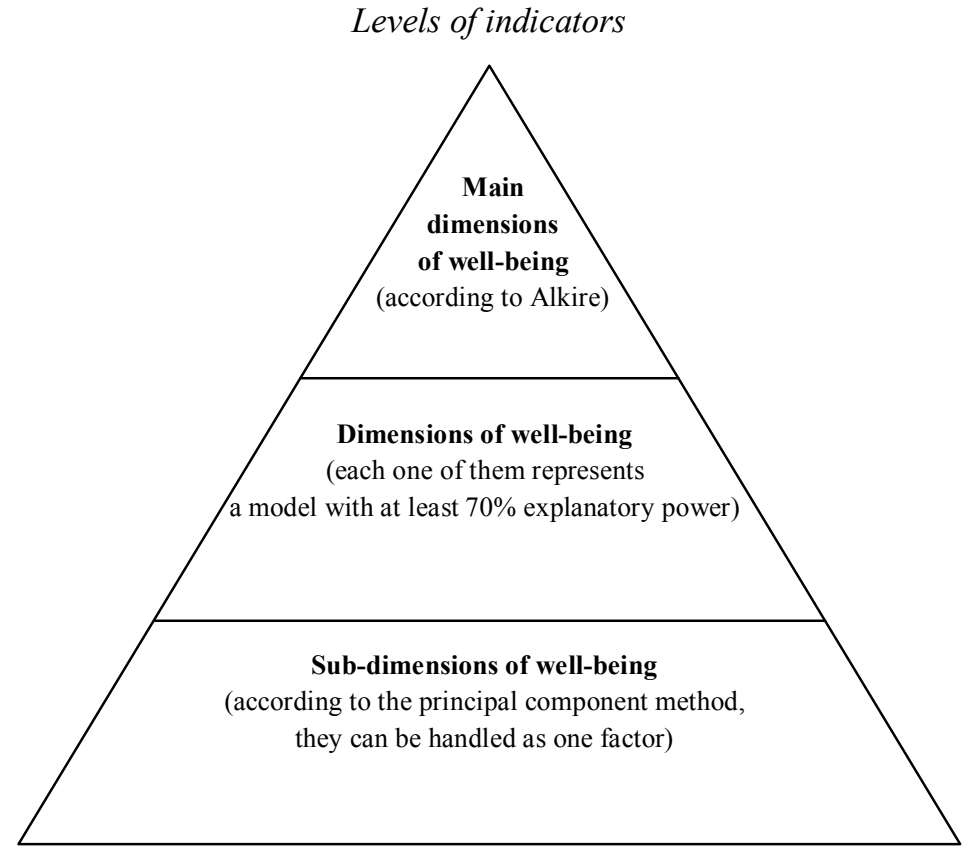

Source: Own illustration.

In the third step of our analysis we specified the output of the measurement exercise. The actually used indicators were the basis for two kinds of output. The first are factors or sub-dimensions themselves. According to the process interpreted above, we saved the factor values and used them later in the evaluation. To use this process, it is a basic requirement that the artificial variables or factors should have real - close to reality meaning (see Table 3 ).

The second kind of output is dimensions. Dimensions were made not from the belonging factors, but from the variables themselves related to the factors with a weighting process. The factor analysis attributes a communality value to each variable. These values show the weight of the variable in the hypothetical or artificial variable. Therefore this is one kind of weighting which is offered by the applied method.

As a consequence, the value of one dimension is the average of the included standardised variables where the weights are the square root of the communalities. It is important to emphasise that not every main dimension was divided into dimensions (some of the main dimensions had $70 \%$ explanatory power in themselves). ${ }^{1}$ During the analysis, the main dimensions with high explanatory power were counted as one of the

1 For instance, the theoretical main dimension of Financial goods was kept as a single dimension, because the three indicators in them (Inland incomes, Poverty rate, Sub-regional Gini index) have more than $70 \%$ explanatory power (see Appendix 1). 
dimensions of well-being. Thus in the analysis for well-being at sub-regional level, we had the following 11 dimensions:

- Financial goods (3 indicators)

- Physical well-being (4 indicators)

- Leisure activities - culture (7 indicators)

- Leisure activities - recreation (4 indicators)

- Labour (1 indicator)

- Forms of basic social care (5 indicators)

- Forms of social care - healthcare (4 indicators)

- Forms of social care - childcare (6 indicators)

- Forms of social care - basic education (5 indicators)

- Forms of social care - safety (5 indicators)

- Education (3 indicators)

Main dimensions, sub-dimensions and their connection to actual meaning

\begin{tabular}{|c|c|c|}
\hline Theoretical main dimension & Dimension & Sub-dimension (factor) \\
\hline Financial goods & $\begin{array}{l}\text { Financial or material } \\
\text { well-being }\end{array}$ & $\begin{array}{l}\text { Income deprivation } \\
\text { Income distribution }\end{array}$ \\
\hline Physical well-being & Physical well-being & $\begin{array}{l}\text { Cancer-type illness } \\
\text { Other long-term illness }\end{array}$ \\
\hline Leisure activities & Culture & $\begin{array}{l}\text { Opportunities for public culture } \\
\text { Opportunities to visit cinema/theatre } \\
\text { Opportunities to visit museums }\end{array}$ \\
\hline & Recreation & $\begin{array}{l}\text { Availability of recreation facilities in town } \\
\text { Quality of recreation facilities }\end{array}$ \\
\hline Labour & Labour & Unemployment \\
\hline \multirow{5}{*}{ Forms of social care } & Forms of basic social care & $\begin{array}{l}\text { Sewage system } \\
\text { Sanitation } \\
\text { Availability of post offices in town }\end{array}$ \\
\hline & Healthcare & $\begin{array}{l}\text { Availability of basic health care services } \\
\text { Hospitals }\end{array}$ \\
\hline & Child care & $\begin{array}{l}\text { Quality of kindergartens } \\
\text { Availability of kindergartens } \\
\text { Endangered minors }\end{array}$ \\
\hline & Basic education & $\begin{array}{l}\text { Availability of primary schools } \\
\text { Quality of primary school education }\end{array}$ \\
\hline & Safety & $\begin{array}{l}\text { Crime } \\
\text { Safety of travelling }\end{array}$ \\
\hline Education & Education & Availability of education \\
\hline
\end{tabular}




\section{Results}

To analyse the well-being situation of sub-regions, we made clusters along the examined dimensions and made groups from sub-regions in similar situations. The result of our cluster analysis is shown in Tables 4 and 5.

\section{Cluster centres}

Table 4

\begin{tabular}{|c|c|c|c|c|}
\hline \multirow{3}{*}{ Well-being dimensions } & \multicolumn{4}{|c|}{ Clusters } \\
\hline & 1 & 2 & 3 & 4 \\
\hline & \multicolumn{4}{|c|}{ Final cluster centres } \\
\hline Financial goods (inverse) & -0.110 & 0.509 & -0.341 & -0.363 \\
\hline Physical well-being (inverse) & 0.061 & 0.279 & -0.363 & -0.337 \\
\hline Leisure activities - culture & 0.069 & -0.320 & 0.133 & 1.537 \\
\hline Leisure activities - recreation & -0.084 & -0.183 & 0.323 & -0.060 \\
\hline Labour (inverse) & -0.330 & 1.279 & -0.784 & -0.730 \\
\hline Forms of basic social care & -0.062 & -0.418 & 0.565 & -0.570 \\
\hline Forms of social care & -0.179 & -0.400 & 0.745 & -0.877 \\
\hline Forms of social care - childcare & 0.061 & -0.454 & 0.367 & 0.200 \\
\hline Forms of social care - basic education & 0.062 & -0.058 & -0.187 & 2.463 \\
\hline Forms of social care - safety & -0.087 & -0.270 & 0.473 & -0.937 \\
\hline Education & 0.142 & -1.026 & 0.861 & -0.143 \\
\hline
\end{tabular}

Size of the clusters

\begin{tabular}{c|c}
\hline Cluster & Number of sub-regions in the cluster \\
\hline 1 & 73 \\
2 & 50 \\
3 & 48 \\
4 & 3 \\
All & 174
\end{tabular}

As we can see, there are only three sub-regions in the fourth cluster (Öriszentpéter, Pécsvárad, Szob). Here well-being seems to be mixed and diverse. These sub-regions prosper in some of the dimensions (Financial goods, Physical well-being, Leisure activities, Labour, Basic education) compared to other sub-regions in the country. However, in other dimensions (Recreation, Education) these regions are slightly below average, while well-being is poor as regards some dimensions (Forms of basic social care, Healthcare, Safety).

The other three clusters are much more homogenous. In the first cluster, we find subregions where the employment situation is relatively good and overall well-being is about average. The exception is the dimension of Healthcare, because here the cluster is below average. Sub-regions in the second cluster have a relatively low level of well-being, while for those in the third cluster the level is relatively high. In the third cluster every dimension has higher values than those in the second cluster, except Basic education. The same is true for the first and third cluster. This simple relationship between the clusters 
becomes more complicated and less homogenous when we analyse the variance between the values. In the case of the second cluster, the variance of Physical well-being around the centre of the cluster is high; the sub-regions in this cluster vary greatly compared to the value attributed to the centre of the cluster. In the case of the third cluster, the same can be said about the dimensions of Leisure activities - recreation and Forms of social care - Healthcare.

Figure 2

Clusters of well-being at sub-regional level

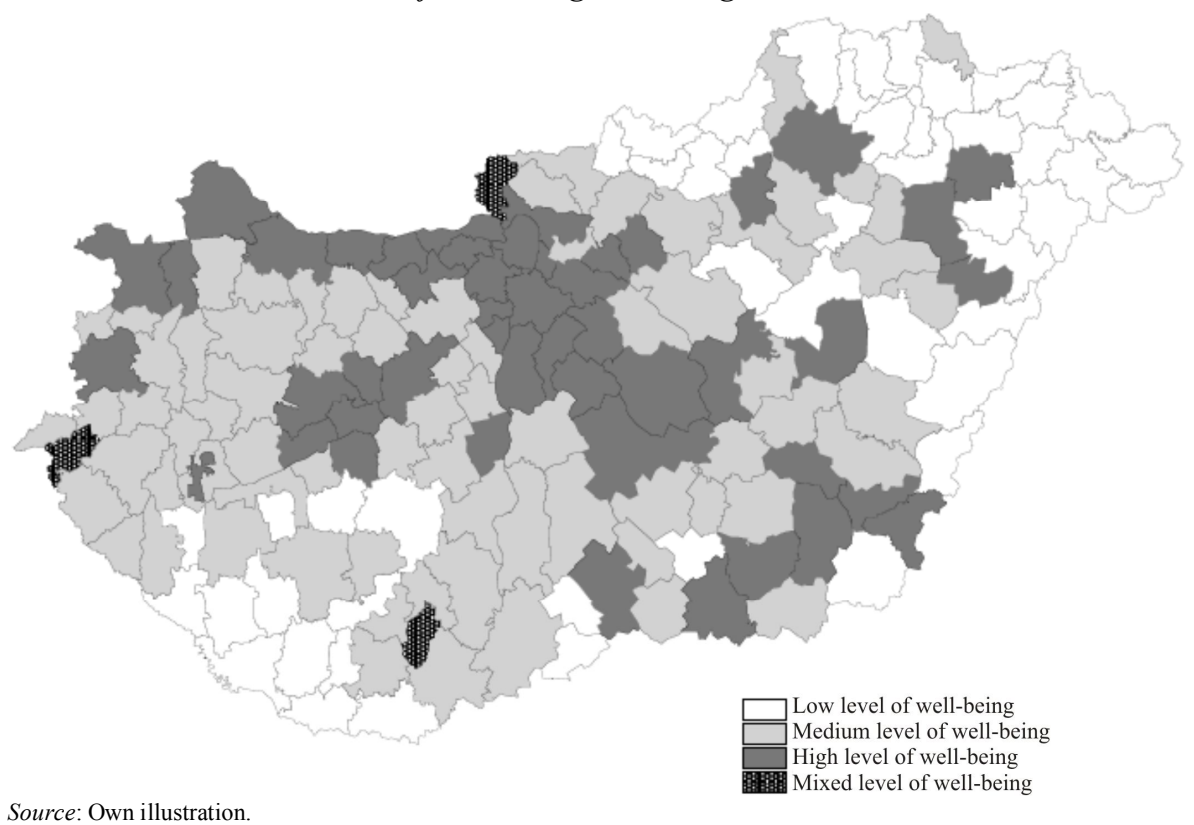

If we analyse the results in a national comparison (see Figure 2), we find that the subregions with relatively high well-being are located around a north-west and south-east axis. The regions around Lake Balaton with high well-being and some of the bigger cities in the eastern part of Hungary (Eger, Miskolc, Nyíregyháza, Debrecen) are outside this axis. It seems that the distribution of sub-regions with higher well-being is influenced by the route of highways, because there is a significant spatial concentration alongside the most important roads. It is important to emphasise that there is a concentration of subregions with high well-being in the agglomeration of Budapest. In contrast, we find subregions with the lowest well-being in the north-eastern and south-western parts of Hungary, primarily in the North Hungary and South Transdanubia regions.

\section{Discussion}

As aforementioned, our main aim was to create a synthesis between different theories of well-being in our study. We tried to include as many aspects of well-being as possible. Consequently, we included much more information in our research than conventional 
welfare or competitiveness analyses, which usually use only price-based SNA indicators and/or employment/unemployment levels. Although we also used income-related indices and unemployment rates, these are not the only indicators but rather only one of the components in our complex analysis of well-being. We claim that this type of multidimensionality and the resultant wide informational base are the main advantages of our research perspective.

Therefore, it is small wonder that our outcome shows differences compared to the results of the traditional economic or competitiveness measurement. ${ }^{2}$ Not only do the single dimensions differ (which are obviously different, because they measure different things), but also our analysis gives a more detailed and diverse picture of sub-regional well-being compared to SNA and competitiveness results (Lukovics-Kovács 2011) or HDI results (Garami 2009).

Although here we do not have the opportunity to give a detailed analysis of these differences, we illustrate them by a brief comparison. Figure 3 shows sub-regional HDI results (Garami 2009). By comparing the two maps (Figures 2 and 3), one can see that they give a somewhat different picture of sub-regional well-being in Hungary. While a north-west south-east axis is present in our results, the HDI analysis implies a better developed north-western part of Hungary - which is more nuanced in our analysis shown in Figure 2.

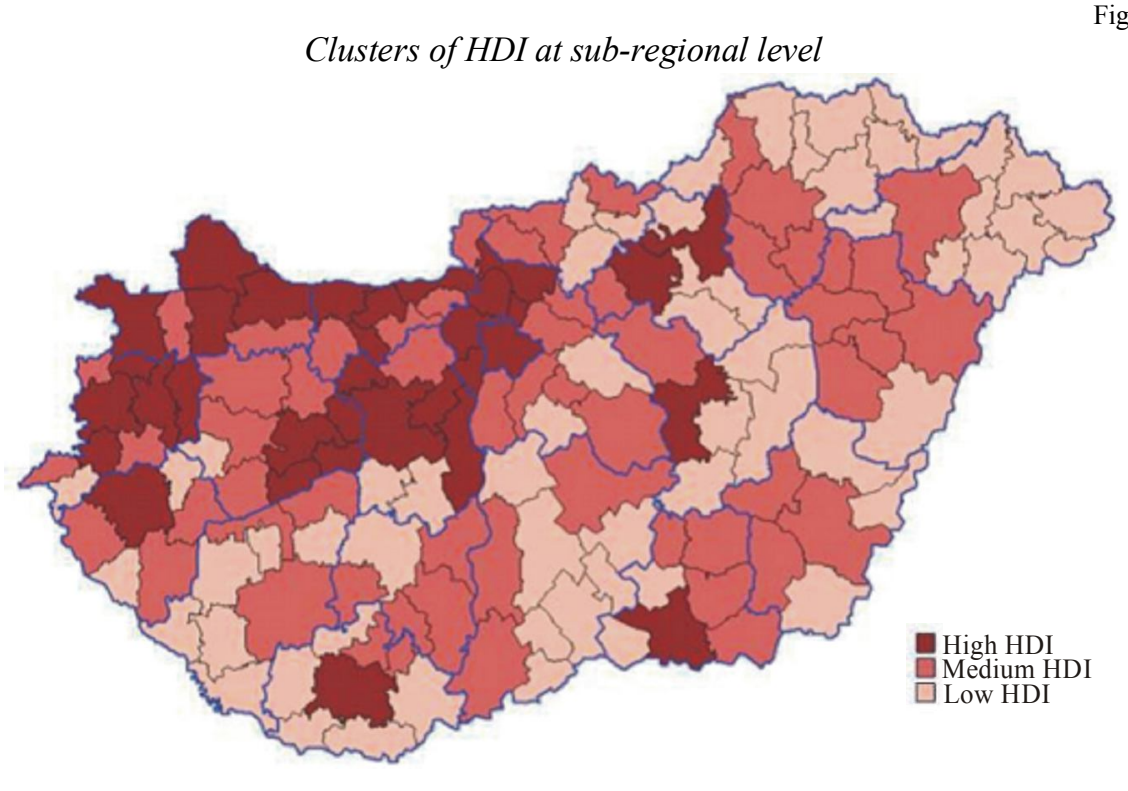

Figure 3

Source: Garami 2009

During our research we realised that we had to face serious limitations and possible biases if we wanted to keep the broad informational base of our analysis. We think that these limitations and their consequences on scientific work regarding well-being 
measurement (in Hungary) are at least as important from a scientific point of view as our results related to Hungarian sub-regional well-being are. The reason is that biases similar to the ones we encountered are likely to occur with any well-being measurement using a wide informational basis. Therefore we discuss these biases below in detail.

The biases are: (1) the arbitrariness of choosing dimensions and statistical tools; (2) the operational gap between the foundational level and the practical level of our research; and (3) the constraints caused by data availability.

(1) It can be argued that our research suffers from arbitrariness in two ways. First of all, there is the uncertainty of the statistical methods used. Both the results of factor analysis and clustering depend very much on the decisions of the researcher. In factor analysis the researcher decides which factor should be filtered out, and how to rotate or iterate the variables. The same can be said about clustering: the characterisation of the different clusters depends on the researcher's choices.

The other form of arbitrariness, often mentioned in the literature of contemporary welfare economics as well (Alkire 2002, Alkire at al. 2008), is that the choice of dimensions is arbitrary and depends only and exclusively on the evaluation of the researcher ${ }^{3}$. It is also debatable whether the dimensions we created are constituents of well-being or not. Also, there may be aspects which are missing from our study but may be deemed important by another evaluation. However, as Sen (1999) argues, we can avoid the overgeneralisation of an arbitrary view of well-being if we make these limitations and decisions explicit and do not claim that the results are general, exclusive and objective.

(2) A significant limitation of our research results from the operational gap between the foundational or conceptualised level and the empirical level of analysis in the study. After creating the list of dimensions, we had to face the fact that some of them were difficult or even impossible to quantify or measure. Five main dimensions had to be ruled out (Rights for freedom, Information access, Relationship with family/friends, Basis of social self-respect and Quality of environment) because they were considered as immeasurable (Berg-Schlosser 2004). Although there are techniques to operationalise these notions, like rights for freedom (see for instance Berg-Schlosser 2004), there are no indicators available on them for the Hungarian sub-regions at the moment. Thus to measure them would involve a whole new research project demanding significant financial resources.

(3) The last significant constraint (bias) of our research is data availability. We realised that databases which are available in Hungary at the moment are of poor quality if one is to operationalise sub-regional well-being. This is true for even those dimensions of well-being where we managed to find some related data (indicators). Although some of the dimensions - like Financial status or Forms of social care - are theoretically easier to quantify than for example Rights for freedom or Information access, even for these dimensions we found a very low number of indicators to represent them.

3 This arbitrariness is true even if the selected dimensions have theoretical underpinning. First of all, the list of dimensions of well-being is - and will always be - incomplete. One can always add another important dimension. Thus, choosing the relevant dimensions incorporates the decision of the researcher. Second, dimensions are normative notions and not prescriptive in any sense. 
For instance, in the case of basic education, we measured the quality of education with the available five indicators: primary school performance, the number of classes per 1000 pupils, the number of full-time primary school teachers per 1000 pupils, the number of computers and the number of primary schools per settlement. It is not hard to see that, for example, to measure the quality of education to a better extent we could include other indices as well, e.g. performance indices revealing skills gained from education (Stiglitz et al. 2009).

As we chose our indicators from existing databases, our research was constrained by already existing measures. As a consequence, our study has become less theory-driven since we could not measure well-being in a way contemporary well-being theory would suggest. Instead, because we relied on available indicators, our research is rather information/data-driven. This means that we had to adjust our measurement to the data currently available and rely less on theory. As a result, our study might show a significantly biased and/or limited picture of well-being from a theoretical point of view. However, after reviewing the literature (van den Bergh 2007, Stiglitz et al. 2009, Comim at al. 2008, Robeyns 2006) it seems that basically almost all well-being measures and indicator systems face similar problems.

\section{Summary}

In our study, we analysed the level of well-being in the sub-regions of Hungary. At the foundational level we started with conceptualising the notion of well-being according to the theories in contemporary welfare economics. Next we identified different dimensions on three levels of analysis to explain even more aspects of well-being and thus deal with its complexity. After that, we chose indicators from already existing databases to cover these dimensions. We used factor analysis and clustering to scrutinise the well-being level of the sub-regions.

Besides providing different results to earlier Hungarian economic and well-being analyses, our main contribution is a new theoretical conceptualisation of well-being measurement previously unknown in the Hungarian literature. We do not just aggregate different indicators but assign them to different theoretical dimensions of well-being. The advantages of such an analysis are twofold. First, this concept may help to understand the complexity of well-being. Second, it helps to categorise indices into theoretically based broader well-being categories.

Both of these advantages have consequences for policy-making. Local (or subregional) policy-making is generally strongly driven by price-based SNA indicators and/or unemployment levels (Bajmócy 2011) although the well-being of a sub-region is a more complex phenomenon. Therefore our indicator system enables the informational base of policy-making to be broadened. A common problem with such exercises is that they imply a tension between theoretical grounding and practical applicability (Steinbuka et al., n.d.). While it is important for political decision-makers to have simple and easyto-understand indicator sets, this understandability and simplicity may result in a reduced theoretical grounding. Our indicator set is a first attempt to overcome this dilemma. By creating an indicator set based on welfare economic theory, we provide a theoretical grounding. By introducing three levels of aggregation, we create a reduced set of 
relatively easily understandable well-being dimensions. Thus we contribute to practical applicability while retaining a theoretical grounding.

Our main conclusions are twofold. First, our research reveals a much more detailed picture about sub-regional well-being than SNA or competitiveness studies do. One of the main novelties of our research is the broadening of the information base of subregional well-being measurement. Second, we state that well-being measurement in general is quite constrained at the moment, and this is especially true of the opportunities for well-being measurement in Hungary at a sub-regional level. The reasons for this are: (1) the arbitrariness of choosing dimensions and statistical tools; (2) the gap between well-being theory and practical measurement; and (3) constraints resulting from data availability. It seems to us that statistical data availability has to improve considerably for researchers to be able to give a comprehensive, theoretically sound and non-data-driven picture of sub-regional well-being in Hungary.

\section{REFERENCES}

Alkire, S. (2002): Dimensions of Human Development. World Development 30 (2): 181-255.

Bajmócy Zoltán (2011): Bevezetés a helyi gazdaságfejlesztésbe. JatePress, Szeged.

Berg-Schlosser, D. (2004): The Quality of Democracies in Europe as Measured by Current Indicators of Democratization and Good Governance. Journal of Communist Studies and Transition Politics 20 (1): 28-55

Böhringer, C. - Jochem, P.E.P. (2007): Survey: Measuring the immeasurable - A survey of sustainability indices. Ecological Economics 63 (1): 1-8.

Comim, F.- Qizilbash, M. - Alkire, S. (eds.) (2008): The Capability Approach - Concepts, Measures and Applications. Cambridge University Press, Cambridge.

Dasgupta, P. (2001): Human Well-Being and the Natural Environment. Oxford University Press, Oxford.

Eurostat (2007): Measuring progress towards a more sustainable Europe. Internet: http://ec.europa.eu/sustainable/docs/estat_2007_sds_en.pdf.

Garami Erika (2009): A humán erőforrás területi különbségei. Az emberi fejlödés indexének hazai alkalmazhatósága. Területi Statisztika 49 (3): 281-298.

Lukovics Miklós - Kovács Péter (2011): A magyar kistérségek versenyképessége. Területi Statisztika 51 (1): $52-71$.

Hanley, N. (2000): Macroeconomic measures of sustainability. Journal of Economic Surveys 14 (1): 1-30.

KSH (Hungarian Central Statistical Office) (2008): A fenntartható fejlödés indikátorai Magyarországon Sustainable development indicators in Hungary. KSH, Budapest.

OECD (2003): OECD Environmental Indicators: Development, Measurement and Use. Reference paper. Internet: http://www.oecd.org/dataoecd/7/47/24993546.pdf.

Hausman, D. M. - McPherson, M. S. (1997): Economic analysis and moral philosophy. University Press, Cambridge.

Málovics György - Bajmócy Zoltán - Fáskerti Zsuzsa - Gébert Judit (2010): Kistérségek jóléti helyzete és ennek innovációs képességgel való kapcsolata a Dél-Alföldi régióban. In: Bajmócy Zoltán (szerk.): A Dél-alföldi régió innovációs képessége. Elméleti megközelitések és empirikus elemzések. (CD Book), pp. 419-468. SZTE Gazdaságtudományi Kar, Szeged.

Nussbaum, M. (2011): Creating capabilities: the human development approach. Belknap Press of Harvard University Press, Cambridge.

Rawls, J. (1971): A Theory of Justice. Oxford University Press, Oxford.

Robeyns, I. (2006): The Capability Approach in Practice. The Journal of Political Philosophy 14(3): 351-376.

Sen, A. K. (1993): Capability and Well-Being. In.: Nussbaum, M. - Sen, A. K. (eds.) The Quality of Life. Oxford, Oxford University Press.

Sen, A. K. (1995): Inequality Reexamined. Cambridge University Press, Cambridge.

Sen, A. K. - Williams, B. (ed.) (1996): Utilitarianism and beyond. Cambridge University Press, Cambridge. 
Sen, A. K. (1999): Development as Freedom. Oxford University Press, Oxford.

Šteinbuka, I. - Wolff, P. (2007): Indicators and better policy-making: the case of sustainable development. http://epp.eurostat.ec.europa.eu/portal/page/portal/sdi/files/LISBON\%20ISI\%20AUG\%202007\% 20REV2.PDF.

Stern, N. (2006): Stern Review on the Economics of Climate Change. http://www.hm-treasury.gov.uk /independent_reviews/stern_review_economics_climate_change/stern_review_report.cfm.

Stiglitz, J. E. - Sen, A. K. - Fitoussi, J. (2009): Report by the Commission on the Measurement of Economic Performance and Social Progress. http://www.stiglitz-sen-fitoussi.fr/en/index.htm.

Streeten, P. (1979): From growth to basic needs. Financial Development 19(3): 28-31.

UN (2007): Indicators of Sustainable Development:Guidelines and Methodologies. United Nations, New York. van den Bergh, J. C. J. M. (2007): Abolishing GDP. TI Discussion Paper, 07-019/3. http://papers.ssrn.com /sol3/papers.cfm?abstract_id=962343.

Keywords: well-being, sub-regions, measurement.

Abstract

Well-being measurement has been an intensively discussed topic in recent economic literature. It has become clear that the informational base of the System of National Accounts (SNA) is far too narrow to include many aspects of well-being. Many economists emphasise that new economic measures which are more sensitive to the social and environmental aspects of decision-making are needed (van den Bergh 2007, Stiglitz et al. 2009) in order to make social decision-making itself sensitive to such aspects. It is small wonder that we encounter a great many sustainability and well-being indicators in economic literature (Böhringer-Jochem 2007).

In our paper, we establish a model for the well-being measurement of sub-regions based on contemporary welfare economics. Based on our model we operationalise and measure well-being at a sub-regional level within Hungary using statistical data. Our research shows that (1) well-being measurement at a sub-regional level reveals tendencies which are masked by traditional economic and competitiveness analysis and (2) wellbeing measurement has serious limitations, i.e. there is a significant measurement gap between the theoretical models of well-being and their operationalisation based on statistical data sets. 
Appendix 1

\begin{tabular}{|c|c|c|c|}
\hline & Numerator & $\begin{array}{c}\text { Reference } \\
\text { year }\end{array}$ & Denominator \\
\hline & Material welfare & & \\
\hline 1 & Inland incomes & 2007 & Population of the sub-region \\
\hline 2 & $\begin{array}{l}\text { Poverty rate (Number of inhabitants with incomes } \\
\text { less than } 60 \% \text { of the compulsory minimum wage) }\end{array}$ & 2007 & Number of personal tax payers \\
\hline \multirow[t]{2}{*}{3} & Sub-regional Gini index* & 2007 & \\
\hline & Physical well-being & & \\
\hline 4 & Malignant tumours of lungs and bronchial tubes & 2008 & 100000 inhabitants \\
\hline 5 & Malignant tumours & 2008 & 100000 inhabitants \\
\hline 6 & Diseases of the respiratory system & 2008 & 100000 inhabitants \\
\hline 7 & Diseases of the digestive system & 2008 & 100000 inhabitants \\
\hline 8 & Malignant breast tumours & 2008 & 100000 inhabitants \\
\hline 9 & Diseases of the circulatory system & 2008 & 100000 inhabitants \\
\hline \multirow[t]{2}{*}{10} & Infant mortality (Infant death) & 2008 & 1000 births \\
\hline & Cultural services & & \\
\hline 11 & Seating capacity of cinemas & 2008 & 100000 inhabitants \\
\hline 12 & Number of cinema performances & 2008 & 100000 inhabitants \\
\hline 13 & Number of museums & 2008 & 100000 inhabitants \\
\hline 14 & Number of museum exhibitions & 2008 & 100000 inhabitants \\
\hline 15 & Number of creative cultural communities & 2008 & 100000 inhabitants \\
\hline 16 & Number of regular cultural activities & 2008 & 100000 inhabitants \\
\hline 17 & Number of municipalities with cultural institutions & 2008 & $\begin{array}{l}\text { Number of municipalities } \\
\text { in the sub-region }\end{array}$ \\
\hline 18 & Number of municipalities with a public library & 2008 & $\begin{array}{l}\text { Number of municipalities } \\
\text { in the sub-region }\end{array}$ \\
\hline \multirow[t]{2}{*}{19} & Number of cultural institutions & 2008 & 100000 inhabitants \\
\hline & Recreation services & & \\
\hline 20 & Number of municipalities with sports halls, sports grounds & 2008 & $\begin{array}{l}\text { Number of municipalities } \\
\text { in the sub-region }\end{array}$ \\
\hline 21 & Number of municipalities with baths/swimming pool & 2008 & $\begin{array}{l}\text { Number of municipalities } \\
\text { in the sub-region }\end{array}$ \\
\hline 22 & Number of playgrounds, sports grounds and picnic areas & 2008 & 100000 inhabitants \\
\hline 23 & $\begin{array}{l}\text { Surface of playgrounds, sports grounds and picnic areas } \\
\text { Labour opportunities }\end{array}$ & 2008 & 1000 inhabitants \\
\hline 24 & $\begin{array}{l}\text { Number of persons seeking employment for over } 180 \text { days } \\
\text { Forms of social care - Basic forms }\end{array}$ & 2008 & Population aged $15-59$ \\
\hline 25 & Number of flats connected to public drainage & 2008 & $\begin{array}{l}\text { Number of flats in the sub- } \\
\text { region }\end{array}$ \\
\hline 26 & Number of municipalities with public sewage disposal & 2008 & $\begin{array}{l}\text { Number of municipalities } \\
\text { in the sub-region }\end{array}$ \\
\hline 27 & Number of flats connected to drinking water system & 2008 & $\begin{array}{l}\text { Number of flats in } \\
\text { the sub-region }\end{array}$ \\
\hline 28 & Number of flats involved in regular waste collection & 2008 & $\begin{array}{l}\text { Number of flats in } \\
\text { the sub-region }\end{array}$ \\
\hline
\end{tabular}




\begin{tabular}{|c|c|c|c|}
\hline & Numerator & $\begin{array}{c}\text { Reference } \\
\text { year }\end{array}$ & Denominator \\
\hline 29 & Number of municipalities with post office(s) & 2008 & $\begin{array}{l}\text { Number of municipalities } \\
\text { in the sub-region }\end{array}$ \\
\hline 30 & $\begin{array}{l}\text { Number of inhabitants involved in water delivery because } \\
\text { of unsatisfactory quality of drinking water from the aspect } \\
\text { of public health }\end{array}$ & 2008 & 10000 inhabitants \\
\hline \multirow[t]{2}{*}{31} & Number of public wells & 2008 & $\begin{array}{l}1000 \mathrm{~km}^{2} \text { within municipality } \\
\text { boundaries }\end{array}$ \\
\hline & Forms of social care - health & & \\
\hline 32 & Number of municipalities with family doctor & 2008 & $\begin{array}{l}\text { Number of municipalities } \\
\text { in the sub-region }\end{array}$ \\
\hline 33 & $\begin{array}{l}\text { Number of municipalities with outpatient medical } \\
\text { attendance }\end{array}$ & 2008 & $\begin{array}{l}\text { Number of municipalities } \\
\text { in the sub-region }\end{array}$ \\
\hline 34 & Number of municipalities with pharmacy & 2008 & $\begin{array}{l}\text { Number of municipalities } \\
\text { in the sub-region }\end{array}$ \\
\hline 35 & Number of functioning hospital beds & 2008 & 100000 inhabitants \\
\hline 36 & Number of family doctor services & 2008 & 100000 inhabitants \\
\hline 37 & Number of paediatric services & 2008 & $\begin{array}{l}100000 \text { inhabitants between } \\
\text { age } 0-17\end{array}$ \\
\hline \multirow[t]{2}{*}{38} & Number of pharmacies & 2008 & 100000 inhabitants \\
\hline & Forms of social care - child care & & \\
\hline 39 & $\begin{array}{l}\text { Number of places in kindergartens (including special } \\
\text { education) }\end{array}$ & 2008 & $\begin{array}{l}1000 \text { children of kindergarten } \\
\text { age }\end{array}$ \\
\hline 40 & $\begin{array}{l}\text { Number of kindergartens (including special } \\
\text { education) }\end{array}$ & 2008 & $\begin{array}{l}1000 \text { children of kindergarten } \\
\text { age }\end{array}$ \\
\hline 41 & Number of municipalities with kindergartens & 2008 & $\begin{array}{l}\text { Number of municipalities } \\
\text { in the sub-region }\end{array}$ \\
\hline 42 & Number of municipalities with day care & 2008 & $\begin{array}{l}\text { Number of municipalities } \\
\text { in the sub-region }\end{array}$ \\
\hline 43 & $\begin{array}{l}\text { Number of children (from age } 0-17 \text { ) placed under child } \\
\text { protection }\end{array}$ & 2008 & $\begin{array}{l}\text { Number of children from age } \\
0 \text { to } 17\end{array}$ \\
\hline 44 & Number of endangered children (from age 0 to 17 ) & 2008 & $\begin{array}{l}\text { Number of children from age } \\
0 \text { to } 17\end{array}$ \\
\hline \multirow[t]{2}{*}{45} & $\begin{array}{l}\text { Number of children applying for day care but rejected } \\
\text { due to the lack of day care places }\end{array}$ & 2008 & 1000 children of day care age \\
\hline & Forms of social care - basic education & & \\
\hline 46 & Number of municipalities with primary school & 2008 & $\begin{array}{l}\text { Number of municipalities } \\
\text { in the sub-region }\end{array}$ \\
\hline 47 & Number of primary schools (including special education) & 2008 & $\begin{array}{l}1000 \text { children of primary } \\
\text { school age }\end{array}$ \\
\hline 48 & $\begin{array}{l}\text { Number of primary school classes (including special } \\
\text { education) }\end{array}$ & 2008 & $\begin{array}{l}1000 \text { children of primary } \\
\text { school age }\end{array}$ \\
\hline 49 & $\begin{array}{l}\text { Number of full-time teachers (including special } \\
\text { education) }\end{array}$ & 2008 & $\begin{array}{l}1000 \text { children of primary } \\
\text { school age }\end{array}$ \\
\hline 50 & $\begin{array}{l}\text { Number of computers in primary schools (including } \\
\text { special education) }\end{array}$ & 2008 & $\begin{array}{l}1000 \text { children of primary } \\
\text { school age }\end{array}$ \\
\hline
\end{tabular}




\begin{tabular}{|c|c|c|c|}
\hline & Numerator & $\begin{array}{l}\text { Reference } \\
\text { year }\end{array}$ & Denominator \\
\hline & Forms of social care - security & & \\
\hline 51 & Number of assaults & 2008 & 100000 inhabitants \\
\hline 52 & Reported crimes & 2008 & 1000 inhabitants \\
\hline 53 & Accidents caused by vehicles & 2008 & 100000 inhabitants \\
\hline 54 & Number of casualties and serious road accidents & 2008 & 100000 inhabitants \\
\hline 55 & $\begin{array}{l}\text { Number of people seriously injured or killed in road } \\
\text { accidents }\end{array}$ & 2008 & 100000 inhabitants \\
\hline & Education & & \\
\hline 56 & $\begin{array}{l}\text { Average number of completed years of schooling of } \\
\text { inhabitants over } 7 \text { years old }\end{array}$ & 2001 & \\
\hline 57 & $\begin{array}{l}\text { Number of inhabitants who did not complete the first year } \\
\text { of primary school }\end{array}$ & 2001 & Inhabitants over 7 years old \\
\hline 58 & $\begin{array}{l}\text { Number of inhabitants with primary } \\
\text { qualification only }\end{array}$ & 2001 & Inhabitants from age 18 to 24 \\
\hline
\end{tabular}

